WIENER SLAVISTISCHES JAHRBUCH, Band 52/2006, 25-41

(C) 2007 by Österreichische Akademie der Wissenschaften, Wien

FREDERIK KORTLANDT

\title{
On the relative chronology of Slavic accentual developments
}

Last year Georg Holzer proposed a relative chronology of accentual developments in Slavic (2005). Here I shall compare his chronology with the one I put forward earlier $(1975,1989 a, 2003)$ and discuss the differences. For the sake of convenience, I first reproduce the relevant parts of my chronology, omitting asterisks before prehistoric Slavic forms.

1. Proto-Indo-European.

2. Dialectal Indo-European .

3. Early Balto-Slavic. During this period the characteristic lateral mobility of Balto-Slavic accent patterns came into existence.

4. Late Balto-Slavic. During this period the Balto-Slavic accent patterns obtained their final shape.

These developments yielded the following phonological system:

$\begin{array}{llllllll}p & b & & m & & & \\ t & d & s & n & l & r & \\ c & d \dot{z} & & & & & & \\ k & g & & & j & w & & \bar{u} \\ H & & i & \bar{l} & & & u & \bar{o} \\ & & e & \bar{e} & & & \end{array}$

5. E a r ly Slavic. During this period Slavic developed along similar lines as its West and East Baltic sister languages.

5.1. Raising of $\bar{e}$ and $\bar{o}$ before a final resonant, e.g. OCS. mati 'mother', kamy 'stone', Lith. móté, akmuõ, Gr. méttèr, ákmōn. The final resonant was lost after the raising. The acc.sg. ending of the $\bar{a}$-stems was shortened to -am, perhaps in Balto-Slavic times already.

5.2. Labialization of $a, \bar{a}$ and merger with $o, \bar{o}$. This development was posterior to the shortening of the acc.sg. ending of the $\bar{a}$-stems to -am, OCS. $-Q$, because the latter did not merge with the reflex of $-\bar{o} n$, OCS. $-y$.

5.3. Loss of the laryngeals in pretonic and post-posttonic syllables with compensatory lengthening of an adjacent vowel, e.g. golwò $H<$ golHwàH 'head', inst.sg. sūnumi $<$ suHnumi 'son', pīlòH < pHilàH '(she) drank', òpsnowō < òpsnowaH 'base', inst.pl. gènoHmīṣ < 
gènaHmiHs 'women'. The long vowel in the final syllable of the latter words is reflected by the neo-circumflex tone of Slovene osnôva $<$ osnòvā, ženâmi < ženàmī, where the middle syllable received the stress as a result of Dybo's law (see 8.7 and 10.9 below).

5.4. Meillet's law: on the analogy of the end-stressed forms, the laryngeals were eliminated from the barytone forms of paradigms with mobile stress, e.g. SCr. acc.sg. glavu 'head', sinn 'son', where the circumflex points to the absence of a laryngeal, cf. Lith. gálva, sún nu, where the acute tone reflects its original presence.

5.5. Rise of nasal vowels, which I shall write $i N, e N, o N, u N$. This development was blocked before a tautosyllabic stop, where the rise of nasal vowels can be dated to stage 6.5 (see below).

5.6. The loss of final $s$ cannot be dated with precision. A comparison with the development of $s$ in Indo-Iranian, Armenian, Greek and Celtic suggests that final $s$ became $h$ in Early Slavic. It was lost at a later stage (see 6.8 below).

5.7. Rise of $x$ from dialectal Indo-European $s$. This development may have been simultaneous with 5.6.

5.8. Rise of $s, z$ from earlier $\dot{c}, d z^{\prime}$, which had developed from the PIE. palatovelar stops $k$, $g^{\prime}, g^{h}$. This development may have been simultaneous with 5.6 and 5.7.

5.9. Raising before final $-h$. The raising affected $-o i h,-\bar{o} i h$, and $-o N h$, cf. OCS. $2 \mathrm{sg}$. imp. (opt.) nesi 'carry', inst.pl. raby 'slaves', acc.pl. raby, ženy 'women', for which I assume an intermediate stage $-u i h,-\bar{u} i h,-u N h$. It affected neither $-o h$, which yielded $-o$ in the neuter $s$ stems, nor $-\bar{o} h$. It was anterior to the loss of the dental stop in -onts, e.g. ORu. nesa 'carrying', cf. ženy 'wives'.

5.10. Lowering of $u n$ to on before a tautosyllabic stop.

5.11. Depalatalization and rounding of nonsyllabic $i$ to $u$ in dat.sg. $-\bar{o} i$ and inst.pl. $-\bar{u} i h$, which subsequently became $-o u$ and $-\bar{u} h$. This development was posterior to the raising in the latter ending at stage 5.9 because the raising did not affect the gen.sg. ending -ouh of the $u$ stems.

5.12. Delabialization of $o, \bar{o}$ to $a, \bar{a}$. It did not affect the nasal vowel $o N$.

These developments yielded the following phonological system:

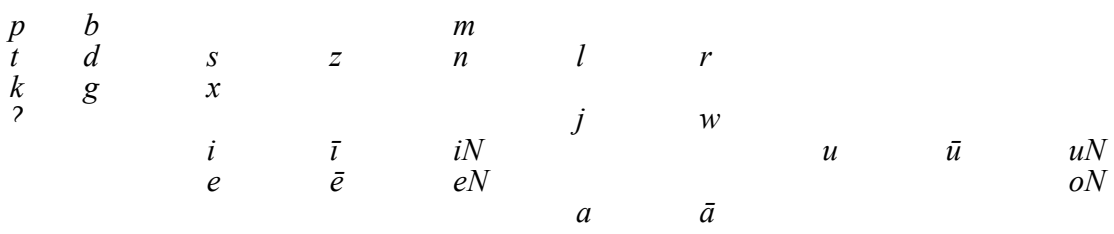

6. Early Middle Slavic. The developments of this period form part of the trend toward rising sonority and synharmonism within the syllable.

6.1. Umlaut. The back vowels $a, \bar{a}, o N, u, \bar{u}, u N$ had fronted variants $\ddot{a}, \bar{a}, \ddot{o} N, \ddot{u}, \bar{u}, \ddot{u} N$ after a preceding $j$. Now $e$ and $\bar{e}$ merged with $\ddot{a}$ and $\bar{a}$, respectively. The nasal vowels $e N$ and $\ddot{o} N$ remained distinct, cf. OCS. $z n a^{2} j o$ 'I know', where the rounding was preserved. The other rounded front vowels also remained phonetically conditioned variants of the corresponding back vowels, e.g. jüga 'yoke'.

6.2. First palatalization of velars: $k>\check{c}, g>d \check{z}, x>\check{s}$ before $e, \bar{e}, i, \bar{l}, j$. The velar obstruents had fronted variants before front vowels. When $e, \bar{e}$ merged with the fronted variants of $a, \bar{a}$ after $j$ (6.1), the sequences $k e, k \bar{e}, g e, g \bar{e}, x e, x \bar{e}$ were rephonemicized as $\check{c} \ddot{a}, \check{c} \ddot{a}, d \check{z} \ddot{a}, d \check{z} \bar{a}, \check{s} \ddot{a}$, $\check{s} \bar{a}$, where $\ddot{a}, \bar{a}$ are the archiphonemes of $e, \bar{e}$ and $a, \bar{a}$ after palatals.

6.3. Spirantization of the voiced affricate $d \check{z}>\check{z}$. This development was blocked by a preceding $z$.

6.4. Palatalization of the dental fricatives: $s>\check{s}, z>\check{z}$ before $j, \check{c}, d \check{z}$.

6.5. Monophthongization of diphthongs: $a i>\bar{e}, e i>\bar{e}, u i>\bar{u}, a u>\bar{o}$. PIE. $e u$ had changed into iou in Balto-Slavic times and into jau at stage 5.12. The occurrence of the diphthong $u i$ was limited to the position before final $h$, where it had arisen at stage 5.9. After palatal consonants the diphthongs $\ddot{a} i, \ddot{u} i, \ddot{a} u$ changed into $\bar{e}, \bar{u}, \tilde{o}$, the latter of which is the phonetically con- 
ditioned variant of $\bar{o}$. The rise of nasal vowels before a tautosyllabic stop can be dated to the same stage. It yielded a new nasal vowel $a N$ in the participial ending PIE. -onts, which had been subject to the delabialization at stage 5.12, e.g. ORu. nesa 'carrying', cf. nesu $<-o N$ 'I carry'. The surviving laryngeals had developed into glottal stops by this time: I shall write $i$, $\dot{e}, \dot{e}, \vec{a}, \dot{o}, \dot{u}$. These sequences had the timbre of the corresponding long vowels.

6.6. Second palatalization of velars: $k>\dot{c}, g>d \dot{z}, x>\dot{s}$ before the new front vowels $\bar{e}$ and $\bar{u}$ which had arisen from the monophthongization of ai, ui (6.5), and after the high front vowels $i, \bar{l}, i N$ unless followed by a consonant or by one of the high back vowels $u, \bar{u}, u N$. The clusters $s k$ and $z g$ became ść and źdź before the new front vowels. The sequences ika, iga, ixa were rephonemicized as ićä, idźä, iśä, etc. The development restored the opposition between $\bar{e}$ and $\bar{a}$ after palatals, e.g. OCS. vbsb 'all', f.sg./n.pl. vbsa, gen.loc.pl. vbsěxz. Thus, the long vowel $\bar{a}$ lost the status of an archiphoneme and came to be the fronted variant of $\bar{a}$ after a palatal consonant.

6.7. Rise of geminated affricates: $t j>t c ́, d j>d d \dot{z}$, also $s t j>s t \dot{c}, z d j>z \dot{z} d d \dot{z}$. This development has a modern parallel in Ukrainian, e.g. żyttjá 'life'. The cluster $k t$ yielded tć before high front vowels, e.g. OCS. noštb 'night', Ru. noč', SCr. nôć.

6.8. Loss of final $h$ from $s$. I date its ultimate loss toward the end of the Early Middle Slavic period because most probably it was only slightly anterior to the rise of prothetic glides (7.1).

6.9. Illič-Svityč's law. Accentual mobility was generalized in the masc. $o$-stems which did not have an acute root vowel, e.g. SCr. zûb 'tooth', cf. Gr. gómphos 'bolt'. The original accentuation seems to have been retained in the Cakavian dialects of Susak and Istria.

6.10. Pedersen's law and rise of distinctive tone. The stress was retracted from inner syllables in accentually mobile paradigms, e.g. Ru. ná vodu 'onto the water', né byl 'was not', pródal 'sold', póvod 'rein'. The stress was also retracted within the initial syllable of barytone forms in paradigms with mobile stress, yielding a falling tone. All other stressed vowels became rising by opposition. This development was posterior to Illič-Svityč's law (6.9) because it eliminated the identity of the two accentual paradigms in the barytone case forms on which the generalization of accentual mobility was based.

These developments yielded the following phonological system:

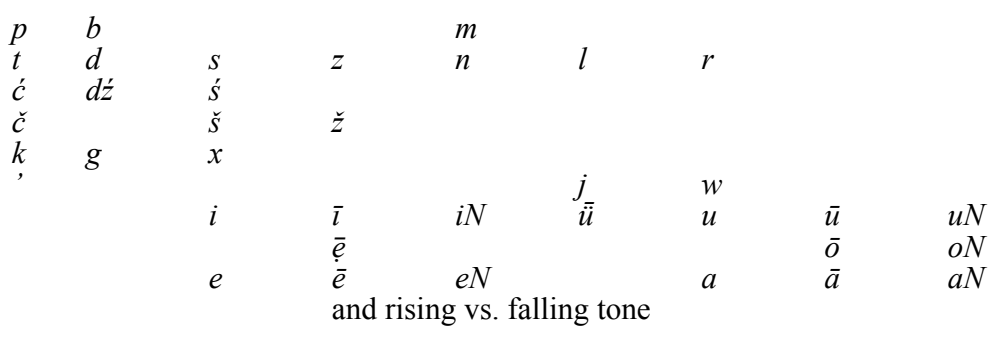

7. Late Middle Slavic. This was the time when the trend toward simplification of the syllable structure reached its culmination and the major dialect divisions established themselves.

7.1. Prothesis. The hiatus between a word-final and a word-initial vowel was filled with a glide, which was $j$ if at least one of the vowels was front and $w$ if the preceding vowel was back and the following vowel was rounded. As a consequence of this development, which was apparently posterior to 6.8 , initial $j$ lost the status of a phoneme before unrounded vowels. Initial jä- and $j a \ddot{a}$-were rephonemicized as $e$ - and $\bar{e}-$, e.g. éxảté < jảxảtẹ 'to ride', Lith. jóti, now with the same initial as éstẹ 'to eat', Lith. ésti. The twofold glide before a rounded vowel gave rise to doublets, e.g. OCS. utro and jutro 'morning', ajce and jajce 'egg'.

7.2. Dolobko's law. Barytone forms of accentually mobile paradigms lost the stress to an enclitic particle, e.g. Slovene lahkî 'light', gen.sg. lahkegà, dat.sg. lahkemù. This development was probably posterior to the rise of distinctive tone (6.10). 
7.3. First simplification of palatals: $c \dot{c}>c, d z>d z$, in South and East Slavic also $s \dot{s}>s, \dot{s}>$ $s c, \dot{z} d \dot{z}>z d z$. The resulting dentals continued to be palatalized for some time.

7.4. The clusters $k^{\prime} w, g^{\prime} w, x^{\prime} w$ which had arisen before front vowels as a result of the second palatalization (6.6) shared the development of 7.3 in South and East Slavic, but were depalatalized in West Slavic. The clusters $k^{\prime} n$ and g' $n$ preserved the palatalization in the nasal.

7.5. Loss of $t$ and $d$ before $l$ in South and East Slavic. As in the case of ść (7.3) and $k w$ (7.4), West Slavic preserved the original cluster.

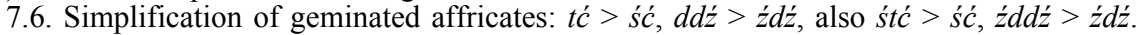
This development was limited to Bulgarian. For the other languages I assume that length shifted from the first, occlusive element of the geminate to its second, fricative element: $t \dot{c}>$

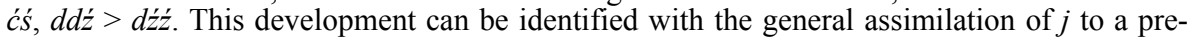
ceding consonant: $\check{c} j>\check{c} \check{s}, \breve{s} j>\check{s} \check{s}, \check{z} j>\check{z} \check{z}, n j>n n, l j>l l l$, also $p j>p l, b j>b l, m j>m l$. The assimilation did not change the phonemic make-up of the clusters because their second components can be regarded as the realizations of the phoneme $/ \mathrm{j} /$ in the respective environments.

7.7. Spirantization of the ungeminated voiced affricate $d z>z$. This development did not reach Lekhitic and a part of the Bulgarian dialects.

7.8. Delabialization of $u, \bar{u}, u N, \ddot{u}, \bar{u}, \ddot{u} N$. This development yielded $y, \bar{y}, y N, i, \bar{\imath}, i N$, e.g. wỷdrả 'otter', lýNka 'bast', iga 'yoke', 2sg. imp. nesī 'carry', acc.pl. arbyN 'slaves', kannniN 'horses'. As a result of the delabialization, the prothetic $w$ before $y, \bar{y}$ received the status of a phoneme. The new $i N$ from $\ddot{u} N$ did not merge with earlier $i N$, which had apparently merged with $e N$ at this stage, e.g. $x w a \bar{l} l e N$ 'praising'.

7.9. Raising of $\bar{e}$ and $\bar{o}$. The empty hole which the delabialization had left was filled by raising the remaining rounded vowel $\bar{o}$ to $\bar{u}$. The corresponding front vowel $\bar{e}<$ PIE. ei was raised to merge with $\bar{\imath}$. The phonetically complex unrounded nasal back vowel $y N$ lost its nasal feature, e.g. lyka 'bast', syta 'hundred'. The corresponding nasal front vowel iN was lowered to $e N$ while $e N$ was lowered to $\ddot{a} N$.

7.10. Retraction of initial $e, \bar{u}$ to $a, \bar{u}$ in East Slavic, e.g. Ru. ózero 'lake', útro 'morning', cf. SCr. jëzero, jütro. čužój.

7.11. Dissimilation of $/ \mathrm{j} /$ in the word for 'foreign' in South Slavic, e.g. SCr. tĥd, Ru.

7.12. Metathesis of liquids in South Slavic and Czecho-Slovak. The metathesis was often accompanied by lengthening. The timbre of the vowel shows that the metathesis was anterior to the rise of the new timbre distinctions (7.13) in Czecho-Slovak and South Slavic, but posterior to that development in Lekhitic and Sorbian. The metathesis did not reach East Slavic except in word-initial position, where it was early in the entire Slavic area, e.g. Ru. rálo 'plough', Cz. rádlo < ảrdla.

7.13. Rise of the new timbre distinctions. In posttonic syllables the glottal stop was lost without compensatory lengthening, whereas in stressed syllables it became a feature of the preceding vowel, comparable to the Latvian broken tone. As a result, the timbre distinctions between the short vowels and the acute "long" vowels became phonemically relevant, e.g. wýdra 'otter', süto 'hundred'.

As a result of the rise of the new timbre distinctions, the quantitative oppositions in pretonic syllables were rephonemicized as timbre differences. All pretonic vowels of this stage are reflected as short vowels in the historical languages, e.g. Czech ruka 'hand' < roNkä, SCr. màlina 'raspberry' < malina. The length in SCr. rúka was introduced from the barytone forms such as acc.sg. rukku, while the original short vowel was preserved in the oblique plural form rùkama. Long vowels in posttonic syllables were not shortened, e.g. òsnowā 'base', inst.pl. žènami 'women', where the long final vowel is reflected by the neo-circumflex tone of Slovene osnôva, ženami (see 10.9 below). The alternation between short pretonic and long posttonic vowels in paradigms with mobile stress was removed by the generalization of the long vowel in Serbo-Croatian and the short vowel in Czech and Polish, e.g. SCr. gölüb 'pigeon', žêlūd 'acorn', läbūd 'swan', öblāst 'region', Cz. holub, žalud, labut', oblast. The long vowel was retained everywhere if it did not alternate with a short vowel, e.g. SCr. mjësēc 'month', pënēz 'coin', jästrēb 'hawk', päūk 'spider', Cz. měsíc, peniz, jestř́áb, pavouk. These words had fixed stress on the laryngealized vowel of the first syllable. Both Czech and Serbo-Croatian have a short vowel in a suffix which contained a laryngeal, e.g. SCr. bògat 'rich', sìdit 'angry'. 
7.14. Raising of the low nasal vowels $a N, \ddot{a} N$ to $y N, e N$ in South Slavic, e.g. OCS. nesy, 'carrying', xvale 'praising', ORu. nesa, xvalja.

7.15. Van Wijk's law and loss of /j/. Long consonants (see 7.6 above) were shortened

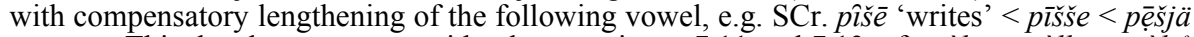
$<$ peisje. This development was evidently posterior to 7.11 and 7.13, cf. wòla $<$ wòlla $<$ wàljả 'will'. New $\bar{e}$ did not merge with earlier $\bar{e}$, which had become $\check{e}$ at stage 7.13.

After the loss of the glottal stop in posttonic syllables and the rise of new long vowels as a result of Van Wijk's law, case endings could have three different quantities. For example, the nom.sg. ending of the $a$-stems was short in žèna 'woman', long in wòļa 'will' and òsnowa 'base', and indifferent with respect to length in gorả 'mountain'. The same distribution holds for the neuter nom.acc.pl. ending. At this stage several levelings took place. Endings which did not occur under the stress were shortened in the whole Slavic territory. Length was generalized in the unstressed nom.acc.pl. ending in Slovene lẹta 'years', but not under the stress, cf. drvà 'firewood'. Conversely, the distinction between a short unstressed nasal vowel and a long nasal vowel under the stress was preserved in Slovene gen.sg. lipe 'lime-tree', goré 'mountain', and in SCr. nom.acc.pl. glâve 'heads', gen.sg. glávē. This difference became phonemic as a result of Dybo's law (see 8.7 below), which reintroduced long unstressed nasal vowels and short nasal vowels under the stress.

These developments yielded the following phonological system:

\begin{tabular}{|c|c|c|c|c|c|c|c|c|c|}
\hline$p$ & $b$ & & & $m$ & $w$ & & & & \\
\hline$t$ & $d$ & & & & & & & & \\
\hline$c$ & $d z$ & $S$ & $z$ & $n$ & $l$ & $r$ & & & \\
\hline$\dot{c}$ & $d \dot{z}$ & $\dot{s}^{\prime}$ & & $n$ & $l$ & $r$ & & & \\
\hline$\check{c}$ & & $\check{s}$ & $\check{z}$ & & & & & & \\
\hline$k$ & $g$ & $x$ & & & & & & & \\
\hline$i$ & $\bar{l}$ & & $\ddot{u}$ & $\begin{array}{l}\bar{u} \\
\ddot{u}\end{array}$ & & $y$ & $\bar{y}$ & $u$ & $\bar{u}$ \\
\hline$e$ & $\bar{e}$ & $e_{p} N$ & & $\ddot{o} N$ & $b$ & $b$ & & $o$ & $o N$ \\
\hline$\ddot{a}$ & $\bar{a}$ & $\ddot{a} N$ & & & & $a$ & $\bar{a}$ & & \\
\hline
\end{tabular}

8. Y oung Proto-S lavic. The redundancies which the trend toward rising sonority had created evoked a reaction, which eventually led to the disintegration of the prosodic system and to the rise of new closed syllables.

8.1. Contractions in posttonic syllables, e.g. Čak. (Novi) pitāa 'asks', Bulg. pita, cf. Čak. kopâ < kopả(j)e 'digs', Bulg. kopáe, Old Polish kopaje. This development was posterior to the rise of the new timbre distinctions (7.13) because new $\bar{e}$ did not merge with earlier $\bar{e}$, which became ě, cf. Czech gen.sg. nového 'new'.

8.2. Retraction of the stress from final jers, e.g. Slovene gen.pl. gọ́ $<$ gorì 'mountains'. Pretonic jers in inner syllables could not receive the stress, e.g. Slovene gen.pl. óvac $<$ owbci 'sheep', Ru. dat.pl. détjam < détbmì 'children' (with -jam for ORu. -em). This development gave rise to new long vowels, which subsequently spread to the gen.pl. forms of other accent types.

8.3. Raising of $\check{e}$ from $\ddot{a}$ to $i e$ in Slovene, Sorbian, Czecho-Slovak, and East Slavic. This development can be dated to approximately the same stage as the retraction of the stress from final jers (8.2) because $\check{e}$ became the counterpart of $\bar{o}$ in these languages. It also affected Serbo-Croatian, though perhaps slightly later and not to the same extent, cf. Čak. (Rab) gnjāzdö 'nest'.

8.4. Merger of palatal fricatives: $s \dot{s}>$, also $s \dot{s}>\check{s} \check{c}, \dot{z} d \dot{z}>\check{z} d z ́$.

8.5. Merger of palatal clusters: $\check{s} \check{c}>\check{s} \check{c}, \check{z} d \check{z}>\check{z} d \dot{\text {. }}$.

8.6. Second simplification of palatals: $c \dot{c}>c, d \dot{z}>d z$ in West Slavic, and subsequently $d z>$ $z$ in Czech and Sorbian; $\dot{c}>\check{c}, d z \dot{z}>d \check{z}>\check{z}$ in East Slavic. The clusters $\check{s} c ́$ and $\check{z} d z ́$ were reduced to $\check{s} t$ and $\check{z} d$ in Bulgarian and the eastern dialects of Serbo-Croatian, and later in CzechoSlovak. Similarly, the clusters $s c$ and $z d z$ became $s t$ and $z d$ in a part of the Bulgarian dialects. 
8.7. Dybo's law: rising vowels lost the stress to the following syllable, if there was one, e.g. ženà 'woman', osnòwā 'base'. Newly stressed long vowels received a falling tone, e.g. wolta 'will'. Final jers had lost their stressability (8.2) and therefore could not receive the stress, e.g. Slovene kònj < kòn ‘ 'horse'. Acute (broken, glottalized) vowels did not lose the stress, e.g. wydra 'otter', dyms 'smoke', which kept fixed stress throughout the paradigm. Dybo's law restored distinctive vowel length in pretonic syllables, e.g. nāròds 'people', $\bar{o}$ Ntròbā 'liver'.

8.8. Lengthening of short falling vowels in monosyllables, e.g. SCr. bôg 'god', kôst 'bone', dân 'day'. This development, which was apparently Common Slavic, eliminated the pitch opposition on short vowels, which had become confined to monosyllables (not counting final jers) as a result of Dybo's law (8.7).

8.9. The inst.sg. ending - $r m b$ of the $u$-stems was generalized in the paradigm of the $o$ stems in North Slavic. It replaced $-a$, which has been preserved in OCS. vbčera 'yesterday' and can be identified with Lith. $-\grave{u}<-o H$. The development was motivated by the merger with the gen.sg. ending $-\bar{a}$ in soft stems as a result of Van Wijk's law (7.15) and can therefore be dated to the Young Proto-Slavic period. The rise of the South Slavic ending -omb requires the continued existence of the nom.sg. ending -os and must therefore be dated to an earlier stage.

These developments yielded the following phonological system:

\begin{tabular}{|c|c|c|c|c|c|c|c|c|}
\hline$p$ & $b$ & & & $m$ & $w$ & & & \\
\hline$t$ & $d$ & & & & & & & \\
\hline$c$ & $d z$ & $S$ & $z$ & $n$ & $l$ & $r$ & & \\
\hline $\begin{array}{l}(\dot{c}) \\
\dot{c}\end{array}$ & $(d \dot{)})$ & & & $n$ & $l$ & $r$ & & \\
\hline$k$ & $g$ & $x$ & & & & & & \\
\hline & & $i$ & & $\ddot{u}$ & & $y$ & & $u$ \\
\hline & & $\begin{array}{l}e \\
(\ddot{a})\end{array}$ & $\begin{array}{l}e N \\
(\ddot{a} N)\end{array}$ & $\ddot{o} N$ & $b$ & $\begin{array}{l}b \\
a\end{array}$ & $\begin{array}{l}(y N) \\
(a N)\end{array}$ & $o$ \\
\hline
\end{tabular}

long vs. short and rising vs. falling tone

9. L a te Proto-S lavi c. This is the last period of common innovations.

9.1. Pleophony in East Slavic, e.g. Ru. ogoród 'kitchen-garden', pozolóta 'gilding'. The development was evidently posterior to Dybo's law (8.7), according to which the prefix lost the stress to the root in these words.

9.2. Loss of the acute (broken, glottalic) tone, which yielded a short rising contour, e.g. dỳmı 'smoke', gorà 'mountain'. This development was posterior to the East Slavic pleophony (9.1) because the distinction between the acute and the earlier rising tone was preserved in Ukrainian, e.g. moróz <-orò- 'frost', gen.pl. holiv< <-oló- 'heads'.

9.3. Stang's law: the stress was retracted from long falling vowels in final syllables, e.g. $w^{u}$ òla 'will', Ru. dial. vôlja, Cz. vi̊le, Slovak vôl'a, Slovene vólja, SCr. völja. The long vowel was shortened, except in Lekhitic, where traces of length remain, e.g. Old Polish wola. The newly stressed vowel received a rising tone. Pretonic jers in inner syllables would not receive the stress, and final jers did not count as syllables with respect to Stang's law. The development was posterior to the loss of the acute tone (9.2), as is clear from SCr. gen.pl. jëzì ka 'tongues'. The short vowel in the first syllable of Cz. jazyk and SCr. jèzik shows that this word had fixed stress on the second syllable before Dybo's law operated: (j)eNzy $k$ r. The retraction in the gen.pl. form points to earlier jeNzŷk from jeNzy kb with analogical lengthening after the loss of the acute tone. If Stang's law had been anterior to the loss of the acute tone, the lengthening would have been impossible and the retraction of the stress would not have taken place in this form. Note that the lengthening was indeed posterior to Stang's law in Čak. (Novi) gen.pl. susêd 'neighbors', kolên 'knees'.

9.4. Shortening of long falling vowels, e.g. Czech mladost 'youth', acc.sg. ruku 'hand', SCr. mlädōst 'youth', gen.sg. präseta 'sucking-pig'. The shortening did not affect monosyllables in Slovene and Serbo-Croatian and the first syllable of disyllabic word forms in the lat- 
ter language, e.g. SCr. bôg 'god', prâse 'sucking-pig', acc.sg. rûku 'hand'. The dialect of the Kiev Leaflets sides with Serbo-Croatian in this respect.

9.5. Proto-Slavic $u$ was fronted to $\ddot{u}$ in the northern dialects of Serbo-Croatian.

9.6. The rounded nasal vowels $o N, \ddot{o} N$ were raised to $u N, \ddot{u} N$ in Serbo-Croatian, Sorbian, Czecho-Slovak, and East Slavic. This development was apparently posterior to the fronting of $u(9.5)$. vak.

9.7. Denasalization of the nasal vowels in East Slavic, and subsequently in Czecho-Slo-

9.8. Rise of the palatalization correlation in Lekhitic, and subsequently in the other North Slavic languages. tic.

9.9. Merger of the jers in Serbo-Croatian, Slovene, and Czech, and subsequently in Lekhi-

10. Dis integrating Slavic. This is the period of parallel but not identical developments in the separate languages.

10.1. The denasalization spread to affect all Slavic languages. The nasal vowels are best preserved in modern Polish.

10.2. The rise of the palatalization correlation affected the languages differently. The correlation is especially characteristic of modern Russian.

10.3. The jers were lost or merged with other vowels under various conditions in the separate languages. They have been preserved as a separate phoneme in Slovene.

10.4. Short rising vowels were lengthened in Russian, e.g. dial. kôn $<k \bar{n} n<k o ̀ n b$ 'horse', cf. $b o g<$ bogr ' $g o d$ ', where the vowel had been shortened (9.4). The length has been preserved in Baltic and Fennic loan words from Russian, e.g. Latvian grāmata 'book', Estonian raamat $<$ gràmotā.

10.5. Short vowels were lengthened in monosyllables in Ukrainian, e.g. kiń $<k \bar{n} n$ 'horse'. Other new long vowels originated from compensatory lengthening before a lost jer in inner syllables.

10.6. Short rising vowels in open first syllables of disyllabic words were lengthened in Czech and Upper Sorbian unless the following syllable contained a long vowel, e.g. Cz. kráva $<$ kràva 'cow', vưle < vōla $<w^{u}$ òla 'will', psáti < pbsàti 'to write', USo. kruwa < krōwa 'cow', Cz. gen.pl. krav, inst.pl. kravami. This development was evidently posterior to the loss of pretonic jers.

10.7. Falling vowels lost the stress to the following syllable in Slovene, e.g. okô 'eye', mladộst 'youth', acc.sg. rokô 'hand'. The newly stressed vowel received a long falling tone. This development was evidently posterior to Stang's law (9.3) and anterior to the loss of the nasal vowels. Indeed, the Freising Fragments can be dated between Stang's law and the progressive accent shift. The accent shift probably originated from the spread of the falling tone over two syllables as a result of the shortening (9.4).

10.8. Stressed short vowels were lengthened and received a falling tone before a non-final lost jer in Slovene, e.g. bitka 'battle'. This development was evidently posterior to the progressive accent shift (10.7).

10.9. Stressed short vowels were lengthened and received a falling tone in Slovene if the following syllable contained a long vowel, which was shortened, e.g. lẹta 'years', osnôva 'base', inst.pl. ženâmi 'women'. The development was evidently posterior to the progressive accent shift (10.7).

10.10. The stress was retracted from a final syllable to a preceding long vowel in Lekhitic, Slovene, and dialects of Serbo-Croatian, where the retraction yielded a rising tone.

10.11. Stressed short vowels in non-final syllables were lengthened and received a rising tone in Slovene, e.g. léto 'year', vólja 'will'. This development, which was posterior to the rise of the neo-circumflex $(10.8,10.9)$ and to the retraction of the stress to a preceding long vowel (10.10), did not reach the easternmost dialects of the language.

10.12. The stress was retracted from a final short vowel in Lekhitic, the Pannonian dialect of the Kiev Leaflets, dialects of Slovene and Serbo-Croatian, and Bulgarian. This retraction, which generally yielded a rising tone, was followed by others in various dialectal areas. In literary Serbo-Croatian, a rising tone points to a retraction of the stress from the following syl- 
lable because the Proto-Slavic rising tones have become falling. Czech and Slovak have fixed stress on the initial syllable, and the same can be assumed for Old Polish.

Here I have to add the following chronology for the metathesis of liquids, which I have presented elsewhere (2003: 232):

(1) lengthening before tautosyllabic resonants in South Slavic,

(2) word-initial metathesis ( $=7.1$ ?),

(3) lengthening before tautosyllabic resonants in Czecho-Slovak,

(4) loss of $t$ and $d$ before $l$ in South and East Slavic (7.5),

(5) non-initial metathesis in South Slavic and Czecho-Slovak (7.12),

(6) rise of the new timbre distinctions (7.13),

(7) lengthening under the stress before tautosyllabic resonants in Polish and Sorbian,

(8) non-initial metathesis in Polish and Sorbian (=7.15?), e.g. Po. bruzda, USo. brózda, Cz. Slk. SCr. brázda 'furrow',

(9) Dybo's law (8.7),

(10) loss of the acute, which yielded a short rising tone (9.2),

(11) lengthening of short rising vowels in Czech and Upper Sorbian (10.6), e.g. Cz. kráva, USo. kruwa 'cow', cf. Slk. krava, Po. krowa, SCr. kräva.

In my discussion of Holzer's chronology of Slavic developments, I shall follow his order of presentation (2005: $42 \mathrm{ff}$.), referring to his numbering as $\mathrm{H} 1-\mathrm{H} 35$. Before I can do this, I have to clarify three points where the traditional reconstruction of Proto-Slavic has given rise to misunderstandings about the character and development of the prosodic system, viz. the nature of the acute, the nature of the circumflex, and the nature of the accent paradigms.

The Balto-Slavic acute developed from the Indo-European laryngeal and preglottalized consonants $* \mathrm{H}$ and $* \mathrm{D}$ after a vowel $* \mathrm{~V}$ or tautosyllabic diphthong $* \mathrm{VR}$. It developed into a glottal stop which was lost in pretonic and post-posttonic syllables in early Slavic (5.3), later in other posttonic syllables (7.13), and eventually in stressed syllables (9.2), where it yielded a short rising tone. Holzer's use of a raised dot for the acute is convenient because it allows two interpretations, "sowohl die als prosodisches Merkmal als auch die als eigenes Segment" (2005: 39), but begs the question of its phonological status, which was different at different stages. In fact, the development of a glottal stop into a glottal feature of the preceding vowel (6.5) is fully parallel with the development of a nasal consonant into a nasal feature of the preceding vowel, e.g. $* e n>* \bar{e}$. The development of the glottalic feature into a short rising tone (9.2) is fully parallel with the denasalization of the nasal vowels.

The Balto-Slavic circumflex was simply the absence of an acute, i.e. the absence of glottalization in the syllable. This circumflex yielded a rising tone in Slavic, as it did in Lithuanian. Unfortunately, the term "circumflex" refers to a falling tone in traditional Slavic accentology (e.g. Stang 1957, passim). Since the two types of "circumflex" refer to diametrically opposed phenomena, it is preferable to avoid the word altogether and to use the term "falling tone" for the traditional circumflex and 
the term "rising tone" for its opposite. In a similar vein, one should avoid the term "recessive stress", which is used for the neo-acute in accent paradigm (b) by Stang (1957) and for the falling tone in accent paradigm (c) by Garde (1976). There are no more than three types of tonal feature in Slavic: (a) glottalization, which eventually developed into a short rising tone, (b) rising tones, which could shift to the right or develop from a leftward tone shift, and (c) falling tones, which could arise from a leftward or rightward tone shift and be lost by a following leftward tone shift. For the sake of uniformity, I use the symbols $a$ and $a ́$ (not $\tilde{a}$ ) for short stress and long rising tone not only for Slovene, as is customary, but also for Croatian dialects without neo-Štokavian retraction of the stress.

There were four accent paradigms in Late Balto-Slavic, viz. (1) with fixed stress on an acute stem syllable, (2) with fixed stress on a non-acute stem syllable, (3) with mobile stress alternating between an acute initial syllable and the endings, and (4) with mobile stress alternating between a non-acute initial syllable and the endings. These types have been preserved largely unchanged in Lithuanian, except that types (2) and (4) were subject to Saussure's law (accent shift from a non-acute syllable to a following acute syllable) and that the acute was subsequently lost in final syllables by shortening (Leskien's law) or metatony. In Slavic, type (1) was preserved until the loss of the acute (9.2), type (2) was subject to Illič-Svityč's law (6.9), Dybo's law (8.7), and Stang's law (9.3), type (3) was lost by merging with type (4) as a result of Meillet's law (5.4), and type (4) was subject to Pedersen's law, which gave rise to falling tones in initial syllables (6.10), Dolobko's law, which gave rise to stressed enclitic particles (7.2), to retraction of the stress from final jers (8.2), lengthening in monosyllables (8.8), and shortening in initial syllables (9.4). Types (1), (2) and (4) are known as accent paradigms (a), (b) and (c) in Slavic.

Following Dybo et al. (1990), Holzer posits the former existence of a fourth accent paradigm (d) in Slavic, which allegedly originated from the elimination of initial stress in disyllabic word forms ending in *-os belonging to accent paradigm (b), e.g. *zombos 'tooth', *nebos 'sky', Gr. gómphos, néphos. In fact, there is no reason to assume that this is correct (cf. Vermeer 2001, Langston 2006, Kortlandt 2006). These words originally belonged to accent pattern (b) and later joined accent pattern (c), cf. Slovene uhộ 'ear', gen.sg. ušęs $a$ with progressive accent shift (10.7), nom.pl. ušęsa with retraction of the stress $(10.12)<*-a ̀$ (cf. Valjavec 1897: 198). Holzer's unfortunate adoption of the misconception of "unstressed word forms" from Garde obscures the issues in a number of ways (cf. Kortlandt 1978a: 72-76).

H1. Progressive palatalization of velars. Since I have discussed this development in detail elsewhere $(1984,1989$ b, cf. also Vermeer 2003), there is no reason to return to the matter here.

H2. Monophthongization of diphthongs (6.5). Holzer unfortunately collapses this process with the later delabialization (7.8) and raising (7.9) of front vowels, but not with the delabialization (H7) and raising (H8) of back vowels. His dating of $\mathrm{H} 2$ after $\mathrm{H} 1$ cannot be maintained, as I have demonstrated in the publications just mentioned. 
H3. Second palatalization of velars (6.6). This process includes the progressive palatalization (H1), which had the same output and evidently the same relative chronology.

H4. Word-initial metathesis of liquids (=7.1?). Holzer unduly limits this process to acute syllables. In fact, it was preceded by lengthening of the vowel in South Slavic, but not in North (i.e. West and East) Slavic.

H5. Meillet's law (5.4). Holzer dates this process after the initial metathesis because he finds instances of unstressed $r a$-, la- instead of $r o-$, lo- in North Slavic. These are clearly secondary, however, unlike such instances as Czech role 'field' beside rádlo 'plough', Ukr. rilljá beside rálo, which show that ro- is the phonetic reflex of pretonic acute *arH- (cf. Kortlandt 2005: 128). Meillet's law was earlier than Illič-Svityč's law (6.9) because the latter did not affect nouns with an acute root vowel. It also preceded Pedersen's law and the rise of the falling tone (6.10) because this development eliminated the accentual identity of the barytone case forms on which Illič-Svityč's law was based.

H6. Dybo's law (8.7). I have argued that this development did not shift the stress to word-final jers (1975: 13-19) because these had lost their stressability at an earlier stage (8.2).

H7. Delabialization of $* \bar{u}$ to $* \bar{y}$ (7.8). Holzer dates this process after Dybo's law because of Čak. (Dugi otok) lòtika beside (Rab) loćika < Latin lactūca 'lettuce'. The former word rather looks like a borrowing from Štokavian. Note that the retraction of the stress in lotika cannot have originated from Stang's law (9.3) because the latter was limited to final syllables not counting final jers, giving rise to such alternations as Russian (Pëtr) kúrit versus (vulkan) kuritsja 'smokes', similarly sádit versus (solnce) saditsja 'sets' (cf. Ebeling 1967: 593).

H8. Raising of $* \bar{o}$ to $* \bar{u}(7.9)$.

H9. Metathesis of liquids in South Slavic and Czecho-Slovak (7.12).

H10. * $a>o$ (7.13). This development preceded Dybo's law (8.7), e.g. Čak. (Vrgada) račún, gen. račūnà, Štok. ràčūn, račúna 'account' < Latin ratiōnem.

H11. $* \bar{e}>\check{e}(7.13)$.

H12. $*_{i}>b$ and $*_{u}>{ }_{b}(7.13)$. Holzer dates this change after H10 because of Čak. jàprk 'southwest' $<*$ aprk $<$ Latin a fricus. This is unnecessary because the * $a$ was evidently acute.

H13. First jer epenthesis, e.g. SCr. òganj 'fire', gen.pl. sestárā 'sisters'. I regard these forms as analogical, cf. Čak. (Vrgada) ògań $<*$ ògńb, sèstår $<*$ sèstrb beside analogical sestắr, Hvar sèstor beside sestór, Susak sièstar (cf. Vermeer 1975: 143 on the vowel system of this dialect), and date the epenthesis to a more recent stage (10.3).

H14. Rise of syllabic liquids. Holzer dates this process after the first jer epenthesis because of SCr. vjëtar 'wind' <*větrz, not **vjëtr. In my view, the epenthetic vowel is analogical in this word. I have identified the rise of the syllabic liquids chronologically with the metathesis of liquids (7.12) because it was a common inno- 
vation of South Slavic and Czecho-Slovak except eastern Slovak dialects (2003: 228).

H15. Rise of nasal vowels $(5.5,6.5)$. Holzer gives no reason for dating this process after the rise of the new timbre distinctions $(\mathrm{H} 10-\mathrm{H} 12=7.13)$ and does not discuss the many problems involved (for which see Kortlandt 1979).

H16. Lengthening of short falling vowels in monosyllables (8.8), e.g. SCr. bôg 'god', k̂ेv 'blood', dân 'day'. Holzer formulates this rule as lengthening of a short vowel before a syllable with a weak jer in unstressed word forms. This is less adequate, not only because it begs the question of unstressed word forms (cf. Kortlandt 1978a: 72-76), but also because it is improbable that short vowels were lengthened in unstressed but not in stressed syllables. On the other hand, Holzer's formulation accounts for the length in göspōd 'lord' and kökōš 'hen', which I regard as analogical.

H17. Reaccentuation of unstressed word forms. This process is equivalent to my rise of the falling tone (6.10). Holzer dates it after Dybo's law (H6 = 8.7) in order to avoid the assumption of a tonal distinction on non-acute syllables. He obviously dates it after his lengthening of short vowels in unstressed word forms (H16), which again shows the inadequacy of that rule.

H18. Shortening of final long vowels. This rule is partly equivalent to my loss of the glottal stop in posttonic syllables (7.13) and partly incorrect because non-acute long vowels in posttonic syllables were not shortened, e.g. *òsnowā 'base', inst.pl. *žènami 'women', where the final long vowel is reflected by the neo-circumflex tone of Slovene osnôva, ženâmi (10.9), also Czech dial. inst.pl. chlapý 'fellows', vratý 'gate', cestami 'roads', nami 'us', Slovak nom.pl. mestá 'cities', dievčatá 'girls', srdcia 'hearts' (cf. Stang 1957: 38, Kortlandt 1976: 3 f.). The loss of the glottal stop gave rise to the new timbre distinctions (H10-H12).

H19. Vowel contractions after the loss of intervocalic $j$ or $x$. I have claimed that the contraction was early in posttonic syllables (8.1) and more recent elsewhere (1975: 39, 1982a: 99, 1986: 253 f.), e.g. Carpathian (Ublja) byváu u, bývaš, bývat', byváieme, byváiete, byváu ut' (cf. Broch 1900: 106), with non-initial stress as a result of Dybo's law (8.7), retraction of the stress according to Stang's law (9.3) from *-âšb and *-âtb but not from medial syllables, and restoration of the thematic vowel in *-à(e)me, *-à(e)te on the analogy of *kopàje-, Čak. (Novi) kopâ, Bulg. kopáe, Old Polish kopaje. Incidentally, Holzer's example SCr. zdrävī 'healthy' does not have an old acute but received root stress from the prefix *sì- as a result of Dybo's law, as did spörī 'slow'.

H20. Van Wijk's law (7.15), e.g. *lja $>* l l l a=/$ lja/ $>* l \underline{a}$, where I have dated the rise of the phonetic geminate $* l l l / 1 \mathrm{j} /$ earlier (7.6) than the vowel lengthening with loss of $/ \mathrm{j} /$ in order to explain the development of the consonant system (1982b: 184187). Holzer unduly limits the lengthening (7.15) to stressed short vowels. In fact, there can be no doubt that it also affected accent paradigm (a), where it gave rise to the neo-circumflex in Slovene, e.g. gînem 'I languish', mâžem 'I smear', grîža 'dy- 
sentery', krâja 'theft' (cf. Kortlandt 1976: 4), and in northwest Čakavian (cf. Vermeer 1982: 289-293 and 1984: 362-382). Holzer's dating of Van Wijk's law after Dybo's law $(\mathrm{H} 6=8.7)$ is disproved by the retention of final stress in the masc. jostems of accent pattern (b), e.g. SCr. krâlj 'king', gen. králja. The regular leveling of quantity in unstressed case endings must be dated after Van Wijk's law but before Dybo's law (cf. Kortlandt 1975: 32).

H21. Stang's law (9.3). Holzer does not recognize the falling tone on long vowels in non-initial syllables which arose from Dybo's law and posits a general retraction of the stress from non-acute long vowels. This is incorrect, as is clear from gen.sg. Slovene goré 'mountain', SCr. glávē 'head', Čak. (Susak) vodiè 'water' (c) as opposed to sestrè 'sister' (b), Kajk. (Bednja) ruká 'hand' < *rokęe, nom.pl. Čak. (e.g. Novi) and Posavian vrimená 'times', imená 'names', ramená 'shoulders', telesá 'bodies', loc.sg. Kajk. noćî 'night', pećî 'stove', kos fil 'bone' < *-í (cf. Vermeer 1984: 366-380), inst.pl. Sln. stzbri 'pillars', kostmí. Non-acute long rising vowels in mobile paradigms did not lose the stress. Contrary to Holzer's statement, the accentuation of SCr. mlâdī 'young', drâgī 'dear', Posavian mládī, drágī is analogical, as is clear from Russian molodój, dorogój. The original accent pattern (c) has been preserved in SCr. gùstì 'dense', svètī 'holy', krìvī 'guilty' (cf. Stang 1957: 102), mlàdī, dràgī, glàdnī, gràdskī, glùhī, mèkī, sùhī, bòsī, gòlī (cf. Rešetar 1900: 129), Slovene mehkî, lahkî. Following Kapović (2005: 84), Holzer refers to Stang's law as Ivšić's law I. Though Ivšić in fact recognized the retraction of the stress from non-initial long falling vowels (1911: 159-182), he did not understand the extent of his findings. It appears that Holzer has fallen victim to Ivšić's formulation, which wrongly subsumes SCr. $d r a \hat{g} \bar{\imath}$ under the retraction and attributes $d r a ̀ g \bar{l}$ to a dialect where the retraction allegedly did not take place (1911: 177). It is Stang's great merit that he has identified the relation between the retraction and accent paradigm (b) and distinguished between different retractions of the stress which are reflected in the alternating variants of the root vowel in the paradigm of Slovene kònj 'horse' (cf. Kortlandt 1975: 13-19). As in other instances (e.g. Hirt, Meillet, Van Wijk, Dybo, Winter), a sound law should be called after the person who has identified the body of empirical data where the law is applicable, not after a person who has identified an underlying principle without specifying the limits of its applicability. I would propose to reserve the name "Ivšić's law" for the Kajkavian retraction of the stress from non-initial long falling vowels to a preceding long vowel (cf. Ivšić 1936: 83, 1937: 188, Vermeer 1979: 375 f., Pronk 2006). Note that from a structural point of view, the relation between Dybo's progressive accent shift (8.7) and Stang's retraction of the stress (9.3) is reminiscent of that between the Slovene progressive accent shift and Ivšić's retraction of the stress, though the details are quite different. While Dybo's shift gave rise to long falling vowels in non-initial syllables from which the stress was retracted in accordance with Stang's law, long vowels which lost the stress as a result of the Slovene shift (10.7) were shortened and did not therefore trigger Ivšić's law, according to which the stress was retracted from a neo- 
circumflex (10.9) to a preceding long vowel (cf. also Greenberg 2000: 111 f.). In both cases, the intermediate period may have been short because the system was unstable.

H22. Retraction of the stress from final (8.2) and non-final jers. These are two different processes (cf. also Kortlandt 1976: 2), which Holzer lumps together as Ivšić's law II. As I have argued earlier (1975: 13-19), SCr. böb 'bean' and krâlj 'king' (b) never had final stress in the nom.sg. form because final jers had lost their stressability (8.2) before Dybo's law (8.7). The stress was actually retracted from the final jer in the gen.pl. form of accent paradigm (c), e.g. Slovene gó $r$ 'mountains', Posavian gláv 'heads'. Since I have discussed the analogical spread of vowel length in the gen.pl. forms of accent paradigms (a) and (b) in detail elsewhere (1978b: 282286), there is no reason to take the matter up again here. In SCr. krâsan 'beautiful' and bijjedan 'wretched' $<*_{-}$bn was analogical on the basis of the other forms of the paradigm, where the jer was lost phonetically (cf. Dybo 1968: 154 f.). This process was clearly more recent than Dybo's law, which had shifted the stress to the non-final jer. Czech and Slovak humno 'threshing-floor' show that the root syllable was unstressed before Dybo's law operated, so SCr. gúmno evidently adopted its length from the plural (cf. Kortlandt 2005: 127). The jer epenthesis in oganj 'fire' was clearly more recent than both Dybo's and Stang's laws. The paradigm of jèsam 'am' < *esmb had final stress before Dybo's law already (cf. Stang 1957: 127). Neither Dybo's nor Stang's law operated in *gladbnàja, which had mobile stress (c). As was pointed out above, SCr. glâdnī 'hungry' is analogical while glàdnī is regular; dùžnīk 'debtor' had a pretonic root vowel and a stressed suffix before Dybo's law (8.7) shifted the stress to the endings except final $*_{-} b$, which had lost its stressability at an earlier stage (8.2).

H23. Shortening of pretonic long vowels (7.13), e.g. SCr. dùžnīk, gràdskī. Following Kapović (2005: 90-101), Holzer unduly limits this rule to word forms where the pretonic syllable was followed by at least one long or two short syllables, not counting jers. This formulation obscures the fact that the root of these word forms belongs to accent pattern (c). Long vowels which were stressed before Dybo's law were not shortened, e.g. národ 'people', prijèglas 'umlaut', námjera 'intention', rázlika 'difference', zábava 'amusement'. It follows that the shortening must be dated before Dybo's law (8.7). The short vowel in the oblique plural form tràvama of tráva 'grass' (b) is based on that in rùkama of rúka 'hand' (c), where it was pretonic before Dybo's law, cf. also trâvnī 'grassy', trâvnīk 'pasture' versus rùchn̄, rùčnīk 'towel' (cf. Kortlandt 2005: 127). New pretonic long vowels were introduced by analogy, e.g. trésèmo 'we shake' (c), cf. Čak. (Novi) tresemò.

H24. Shortening of long vowels in the second syllable of quadrisyllabic word forms with initial stress (cf. Kapović 2005: 107). This was a local development of Serbo-Croatian.

H25. Loss of the acute (9.2), which yielded a short rising tone. The loss of the acute preceded Stang's law $(\mathrm{H} 21=9.3)$ because both developments affected gen.pl. 
SCr. jēzì ka 'tongues' < ${ }^{*} j e ̨ z y k b$ with analogical lengthening $<* j e ̨ z y k b$ with loss of the acute (cf. Kortlandt 1975: 16, 34).

H26. Shortening of long falling vowels (9.4). In Serbo-Croatian, as opposed to North Slavic, this shortening did not affect monosyllabic and disyllabic word forms. In initial syllables of polysyllabic word forms, long rising vowels had been eliminated by Dybo's law (8.7) and did not arise from Stang's law (9.3) because the operation of the latter was limited to final syllables. The only instances of long rising vowels in initial syllables of polysyllabic word forms are found in trisyllabic word forms with a medial jer where they arose from retraction of the stress either from a final jer (8.2) or from a long falling vowel (9.3). Holzer's formulation of the shortening as a process that affected stressed long vowels in the initial syllable of polysyllabic words without a jer in the prefinal syllable obscures the fact that the development was limited to accent pattern (c) and that a similar but not identical process is found in the neighboring languages.

H27. Second jer epenthesis (10.3).

H28. Loss of weak jers (10.3).

H29. Merger of strong jers with *a (10.3).

H30. Lengthening of posttonic $e$ and $o$ before final $-n,-r$. This was a local development of Serbo-Croatian which may have preceded the development of the jers $(\mathrm{H} 27-\mathrm{H} 29=10.3)$.

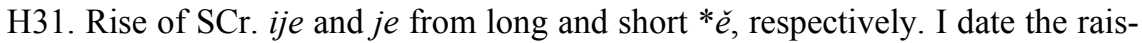
ing and diphthongization of * $\check{e}$ from $* \ddot{a}$ to $* i e$ to an earlier stage (8.3) because the development is also found in Slovene, Sorbian, Czecho-Slovak and East Slavic and because $* \check{e}$ became the counterpart of ${ }^{*} \bar{o}$ in these languages (cf. also Kortlandt 2003: 230). It apparently did not affect Serbo-Croatian to the same extent, cf. Čak. (Rab) gńázdò 'nest'.

H32. Vocalization of syllable-final $l$ to $o$.

H33. Lengthening of vowels before tautosyllabic resonants.

H34. Loss of rising tones (including the neo-acute).

H35. Neo-Štokavian retraction of the stress, which yielded new rising tones. This development was followed by the introduction of new falling tones in non-initial syllables (cf. Vermeer 1985).

The principal differences between Holzer's chronology and mine can now be summarized as follows:

(1) Holzer dates Meillet's law (H5 = 5.4) rather late and Dybo's law (H6 = 8.7) very early. This is a consequence of his assumption of "unstressed word forms" and his unwillingness to recognize tonal distinctions in non-acute syllables. I regard Meillet's law as the first accentual development of Slavic after its separation from Baltic and date Dybo's law after the rise of the new timbre distinctions (7.13), Van Wijk's law (7.15), contractions in posttonic syllables (8.1) and the retraction of the stress from final jers (8.2). 
(2) Holzer does not regard the rise of the new timbre distinctions (H10-H12), the shortening of final long vowels (H18) and the shortening of pretonic long vowels (H23) as a unitary process (7.13). In fact, the shortening of long vowels and the rise of new timbre distinctions are two sides of the same coin. This development opened up the possibility of new long vowels with the timbre of the earlier short vowels. Such new long vowels were indeed created in posttonic syllables by Van Wijk's law (7.15) and by the early contractions (8.1) and in stressed syllables by the retraction of the stress from final jers (8.2) and by the lengthening of short falling vowels in monosyllables (8.8). New long vowels in pretonic syllables arose as a result of Dybo's law (8.7).

(3) Holzer dates Stang's law $(\mathrm{H} 21=9.3)$ before the retraction of the stress from final and non-final jers (H22), the shortening of pretonic long vowels (H23), and the loss of the acute $(\mathrm{H} 25=9.2)$. This chronology is based on a misunderstanding of the relation between these developments and the accent patterns (a), (b) and (c). While Stang's law, the retraction from final jers and the loss of the acute affected paradigms (b), (c) and (a), respectively, the retraction from non-final jers applied to derivatives of (b) roots (cf. Dybo 1968: 152-158 and 174-192) and the pretonic shortening to derivatives of (c) roots (including original acute roots as a result of Meillet's law, e.g. Czech role 'field'). Like the retraction from final jers, Stang's law did not retract the stress to a preceding non-initial jer, e.g. SCr. pöčnēm 'begin', ötnēm 'grab', räzdrēm 'tear up', similarly in Bulgarian and Old Russian (cf. Stang 1957: 115). It follows that the relative chronology of these developments can only be established on the basis of an intervening sound law (Dybo's law after the pretonic shortening and the retraction from final jers but before the loss of the acute and Stang's law) or analogical development (lengthening in the gen.pl. of (a) nouns after the loss of the acute but before Stang's law).

(4) Holzer's chronology is atomistic in the sense that it is established without regard to the structural properties of the phonemic system. In my view, the red thread which runs through the prehistory of Slavic accentuation is the loss of the IndoEuropean laryngeals (cf. already Kortlandt 1975: x-xi). While these lost their distinctive position within the syllable in Late Balto-Slavic times already, the loss of glottalization in pretonic and post-posttonic syllables in Early Slavic gave rise to new long vowels (5.3) and to Meillet's law (5.4), its loss in the first posttonic syllable in Late Middle Slavic to new timbre distinctions and pretonic shortening (7.13), and its loss in stressed syllables in Late Proto-Slavic to new short rising vowels (9.2). The rise of the new timbre distinctions (7.13) created the possibility of new long vowels in posttonic syllables $(7.15,8.1)$, under the stress $(8.2,8.8)$ and in pretonic syllables (8.7). Enhanced differentiation between fixed and mobile accent paradigms (Pedersen's law) gave rise to a tonal distinction in initial syllables (6.10), which created the possibility of a tonal distinction in non-initial syllables (8.7). As the number of potentially distinctive vowels increased dramatically from 10 (5.0) to $12(6.0)$ to $32(7.0)$ to $45(8.0)$ to $69(9.0)$, the vowel system was simplified in Late 
Proto-Slavic by the loss of glottalization (9.2), the loss of falling vowels in non-initial syllables (9.3), shortening of long falling vowels (9.4), loss of nasal vowels (9.7) and merger of the jers (9.9), and later by lengthening of short rising vowels (10.4, $10.6,10.11)$ and by the general loss of tonal distinctions and vowel quantity in most Slavic languages.

Re f e r e n c e s

Broch 1900:

Dybo 1968:

Dybo - Zamjatina - Nikolaev 1990: Vladimir A. Dybo, G. I. Zamjatina, S. L. Nikolaev,

Osnovy slavjanskoj akcentologii, Moskva

Ebeling 1967:

Garde 1976:

Greenberg 2000:

Holzer 2005:

Ivšić 1911:

Ivšić 1936:

Ivšić 1937:

Kapović 2005:

Kortlandt 1975:

Kortlandt 1976:

Kortlandt 1978a:

Kortlandt 1978b:

Kortlandt 1979:

Kortlandt 1982a:

Kortlandt 1982b:

Kortlandt 1984:

Kortlandt 1986:

Kortlandt 1989a:

Kortlandt 1989b:

Olaf Broch, Ugrorusskoe narěčie sela Ubli, Sankt-Peterburg

Vladimir A. Dybo, Akcentologija i slovoobrazovanie v slavjanskom, Slavjanskoe jazykoznanie: VI meždunarodnyj s"ezd slavistov, Praga, 1968, Moskva, 148-224

Carl L. Ebeling, Historical laws of Slavic accentuation, To Honor Roman Jakobson I, The Hague, 577-593

Paul Garde, Histoire de l'accentuation slave, Paris

Marc L. Greenberg, A Historical Phonology of the Slovene Language, Heidelberg

Georg Holzer, Zur relativen Datierung prosodischer Prozesse im Gemeinslavischen und frühen Kroatischen, Wiener Slavistisches Jahrbuch 51, 31-71

Stjepan Ivšić, Prilog za slavenski akcenat, Rad JAZU 187, 133-208

Stjepan Ivšić, Jezik Hrvata kajkavaca, Ljetopis JAZU 48, 47-88

Stjepan Ivšić, Osnovna hrvatska kajkavska akcentuacija u Pergošića (1574), Zbornik u čast A. Belića, Beograd, 183-195

Mate Kapović, The development of Proto-Slavic quantity (from ProtoSlavic to modern Slavic languages), Wiener Slavistisches Jahrbuch $51,73-111$

Frederik Kortlandt, Slavic Accentuation, Lisse; also www.kortlandt.nl Frederik Kortlandt, The Slovene neo-circumflex, The Slavonic and East European Review 54/1, 1-10

Frederik Kortlandt, A history of Slavic accentuation: Review of Garde 1976, Lingua 44/1, 67-91

Frederik Kortlandt, On the history of the genitive plural in Slavic, Baltic, Germanic, and Indo-European, Lingua 45, 281-300

Frederik Kortlandt, On the history of the Slavic nasal vowels, Indogermanische Forschungen 84, 259-272

Frederik Kortlandt, Review of Marvan 1979, Lingua 56/1, 98-100

Frederik Kortlandt, Early dialectal diversity in South Slavic I, Studies in Slavic and General Linguistics 2: South Slavic and Balkan Linguistics, 177-192; also www.kortlandt.nl

Frederik Kortlandt, The progressive palatalization of Slavic, Folia Linguistica Historica 5/2, 211-219

Frederik Kortlandt, The origin of the Slavic imperfect, Festschrift für Herbert Bräuer zum 65. Geburtstag, Köln, 253-258

Frederik Kortlandt, Od praindoevropskog jezika do slovenskog (fonološki razvoj), Zbornik za Filologiju i Lingvistiku 32/2, 41-58; English edition: From Proto-Indo-European to Slavic, www.kortlandt.nl

Frederik Kortlandt, On methods of dealing with facts and opinions in a treatment of the progressive palatalization of Slavic, Folia Linguistica Historica 9/2, 3-12 
Kortlandt 2003: $\quad$ Frederik Kortlandt, Early dialectal diversity in South Slavic II, Studies in Slavic and General Linguistics 30: Dutch Contributions to the Thirteenth International Congress of Slavists, Ljubljana, 2003, Linguistics, 215-235; also www.kortlandt.nl

Kortlandt 2005: $\quad$ Frederik Kortlandt, From Serbo-Croatian to Indo-European, Wiener Slavistisches Jahrbuch 51, 113-130; also www.kortlandt.nl

Kortlandt 2006: $\quad$ Frederik Kortlandt, Miscellaneous remarks on Balto-Slavic accentuation, Tones and Theories: Proceedings from the International Workshop on Balto-Slavic Accentuation [Zagreb 1.-3. July 2005], ed. by Mate Kapović and Ranko Matasović, Zagreb; also www.kortlandt.nl

Langston 2006: Keith Langston, Common Slavic accentual paradigm (d): a reevaluation of evidence from Cakavian, Tones and Theories: Proceedings from the International Workshop on Balto-Slavic Accentuation [Zagreb 1.-3. July 2005], ed. by Mate Kapović and Ranko Matasović, Zagreb

Lehfeldt 2001: $\quad$ Werner Lehfeldt, Einführung in die morphologische Konzeption der slavischen Akzentologie, 2. Auflage, München

Marvan 1979: $\quad$ Jiří Marvan, Prehistoric Slavic Contraction, University Park: Pennsylvania State University Press

Pronk 2006:

Rešetar 1900:

Tijmen Pronk, The retraction of the neocircumflex in the Carinthian dialects of Slovene, Tones and Theories: Proceedings from the International Workshop on Balto-Slavic Accentuation [Zagreb 1.-3. July 2005], ed. by Mate Kapović and Ranko Matasović, Zagreb

Stang 1957:

Valjavec 1897:

Vermeer 1975:

Milan Rešetar, Südslavische Dialektstudien I: Die serbokroatische Betonung südwestlicher Mundarten, Wien

Christian S. Stang, Slavonic Accentuation, Oslo

M. Valjavec, Glavne točke o naglasu kńiževne slovenštine, Rad JAZU $132,116-213$

Willem R. Vermeer, Problems in the synchronic and diachronic phonology of Susak Čakavian, Zbornik za Filologiju i Lingvistiku 18/2, $139-159$

Vermeer 1979: $\quad$ Willem R. Vermeer, Innovations in the Kajkavian dialect of Bednja, Dutch Contributions to the Eighth International Congress of Slavists, Zagreb, 1978, Lisse, 347-381

Vermeer 1982: $\quad$ Willem R. Vermeer, On the principal sources for the study of cakavian dialects with neocircumflex in adjectives and $e$-presents, Studies in Slavic and General Linguistics 2: South Slavic and Balkan Linguistics, 279-341

Vermeer 1984: $\quad$ Willem R. Vermeer, On clarifying some points of Slavonic accentology: the quantity of the thematic vowel in the present tense and related issues, Folia Linguistica Historica 5/2, 331-395

Vermeer 1985: Willem R. Vermeer, Non-initial falling tones in neo-štokavian dialects, Zbornik za Filologiju i Lingvistiku 27-28, 143-149

Vermeer 2001: $\quad$ Willem R. Vermeer, Critical observations on the modus operandi of the Moscow Accentological School, in: Lehfeldt 2001, 131-161

Vermeer 2003: Willem R. Vermeer, Comedy of errors or inexorable advance? Exploring the dysfunctionality of the debate about the progressive palatalization of Slavic, Studies in Slavic and General Linguistics 30: Dutch Contributions to the Thirteenth International Congress of Slavists, Ljubljana, 2003, Linguistics, 397-452

Frederik Kortlandt

Cobetstraat 24

NL-2313 KC Leiden

www.kortlandt.nl 
